$\stackrel{W}{N}$

Global Journals Inc

0 (

\title{
The Foreign Goods Demand, Cultural Beliefs and Consumer Choices: A Microeconomics Note
}

By Dr. Erico Wulf

University of La Serena

Abstract- Consumers react to opportunities. So, given that free trade allows them more alternative goods, ¿How come that foreign goods shape consumer choices?. Is it either because of its price, consumer's income, or their cultural beliefs?. How do it all influence business strategic decisions in international markets? The aim of this paper is to analyze the microeconomic relationship between utility maximization, and cultural values. In particular, its influence in the consumer decisions framework as well as its role for shaping business strategic decisions concerning international markets.

The methodology is an inductive desk research. It begins with the theoretical background about consumer behavior and foreign good demand, as well as cultural values impact on business strategy in foreign markets, to conclude that as incomes rises and needs step up, consumers get involve in wider social interaction, such that it shapes the boundaries of rationality which make cultural values part of the marginal utility of income.

Keywords: consumer decisions, cultural values, preferences, utility maximization, imported goods, strategic management.

GJMBR-E Classification: JEL Code: M30

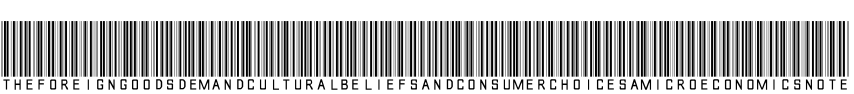

Strictly as per the compliance and regulations of:

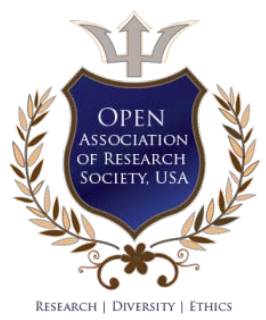

(c) 2021. Dr. Erico Wulf This is a research/review paper, distributed under the terms of the Creative Commons AttributionNoncommercial 3.0 Unported License http://creativecommons.org/licenses/by-nc/3.0/), permitting all non-commercial use, distribution, and reproduction in any medium, provided the original work is properly cited. 


\title{
The Foreign Goods Demand, Cultural Beliefs and Consumer Choices: A Microeconomics Note
}

\author{
Dr. Erico Wulf
}

\begin{abstract}
Consumers react to opportunities. So, given that free trade allows them more alternative goods, ¿How come that foreign goods shape consumer choices?. Is it either because of its price, consumer's income, or their cultural beliefs?. How do it all influence business strategic decisions in international markets? The aim of this paper is to analyze the microeconomic relationship between utility maximization, and cultural values. In particular, its influence in the consumer decisions framework as well as its role for shaping business strategic decisions concerning international markets.

The methodology is an inductive desk research. It begins with the theoretical background about consumer behavior and foreign good demand, as well as cultural values impact on business strategy in foreign markets, to conclude that as incomes rises and needs step up, consumers get involve in wider social interaction, such that it shapes the boundaries of rationality which make cultural values part of the marginal utility of income. The implication for the strategic management decisions in international markets is to set the income segment, which make the most of expected profit abroad.
\end{abstract}

Keywords: consumer decisions, cultural values, preferences, utility maximization, imported goods, strategic management.

\section{INTRODUCTION}

W hile the utility maximization the oryconsiders consumers as efficient decision makers, other theories explain their behavior with the influence of psychological and neo economics variables, aimed to a "better off" second best decisions status, instead of a pure maximization purpose. The main stream theoretical microeconomics frame worker quires to keep qualitative variables as given (tastes and culture), in order to understand the influence of quantitative variables (Price and income), in consumer decisions and utility maximization. Besides, given a predictable time span starting from early consumptions stages, moving forward to those one at the retirement age from the labor force, permanent income set a life cycle pattern of expenditure behavior. Modigliani and Brumberg (1954).

On the other side, the "better off" status, is focus on both qualitative and subjective variables, (consumer mood, tastes, cultural variables, perceptions, intuition, Self esteem), deeply connected with

Author: Associate Professor University of La Serena.

e-mail: ewulf@userena.cl psychology, and lately with the Neuro economics field and the implications for consumer behavior of brain reactions, assuming all those structural variables which provide a sense of inclusiveness and identity with in society (tradition, social mobility, status, engagement and the like) as given. Marim (2016).

Moreover, behavioral economics suggest that consumers don't always follow the expected path, about rationality as anticipated by the economic theory. (Thaler, 2015). This bias may be explained by the nature of the rationality assumptions, which seem to be restrictive to a specific setting about the influence of qualitative variables (tastes), but also because of the unexpected nature of human behavior. (Brook (2012).

As a practical matter, cultural values represents an exogenous common ground for consumer decisions, which in the long run provides the essential framework for other values to develop, such as stability, the rule of law, honesty, transparency, solidarity, ethics, making of its influence to become unavoidable over time. Marim (2016). However, consumers are not fully aware of all of them in the short run although they are essential to increase their welfare level throughout the life time span.

Thus, given any specific situation in the short run about prices and income, rationality behavior may not seems obvious in day by day consumers decisions as long they have different perceptions about daily events, (Levinson (2007), or they may be constrained by a structure setting or context which rationality depends on, (Tversky and Kahneman (1974)), Gigerenger and Goldstein (1996), Kahneman (2003). But in the long run it is hard to think of persistent irrational behavior. Besides, as individuals have uncertainty, they realize that the way to solve such a situation it is to think about the best outcome they expect to get in the long run in which rational adaptation over time, is less costly than deviation from it. Marim (2016)

Therefore, the bounded rationality for consumers is the expected situation about quality and value they face in the short run, given good prices and their income levels. This is different to both:

- The Simon`s proposal (1957), about bounded rationality for uncertainty situations facing management decisions makers, which impose a 
constraint on their short run firms' s performance, and,

- The psychological underlying of economic decisions proposed in the $18^{\text {th }}$ and $19^{\text {th }}$ century, which considered rationality to be influenced by the structure arising from external factors. Gigerenger et al (1996), Tversky et. al (1974), Kahneman (2003) Samson (2004).

Thus, one thing is the uncertainty for consumption, another one is the uncertainty for business. In the former very much of it deals with price and income trends, although in the long run, prices decrease and income increase. The real uncertainty for consumers is about quality and value, such that income shapes the boundaries of rationality. No matter that specificity about uncertainty, the rational foundation of homo economicus has been challenged, as well as the hypothesis that behavior is only based on information.

The Behavior Economics suggest that human decisions are influenced by context and social influences. Thaler (2015). Emotions, cognitive biases, and social setting, are all influencing individual behavior. (Brooks, 2012). Therefore, the Consumer preferences are not only a matter of tastes, but they are also influenced by culture and norms, which differs across societies as it does the institutions they are part of. North (2001), Samson (2014), Marim (2016).

How all the above argument is affected by free trade?. When the economy is open to international trade, some questions arises about consumer decisions: ¿What is it the stand of microeconomics theory, about the cultural framework influencing consumers demand for foreign goods?.¿ Is it either a cultural or an economics choice, which lead to buy foreign goods? ¿How does culture-side of consumer behavior influence strategic management decision in international markets?

The purpose of this paper is to look for preliminary answer to those questions, providing a theoretical explanation concerning the implications of marginal utility analysis as income increase over time, ultimately influencing the substitution of domestic goods for imported ones. Besides, the empirical evidence about cultural values and its relationship with consumer behavior is analyzed, as well as a selected research which fit in the proposed explanative model.

\section{Methodology}

The methodology applied considers the Marginal Utility maximization model, and its important side step implications:

- The Revealed Preference theory, provide the evidence to include foreign goods into the optimal good bundle to widen up its diversification profile, once the economy follow a free trade policy.
- Income has an endogenous dimension settle in through its marginal utility. So, as income rise and needs become more complex, it allows consumers to engage in different social cultural interaction, which lead the Marginal utility of Income, to shape their rationality boundaries and behavior.

- The economic approach to consumer behavior (Becker,1976), provide support to new cultural values arising endogenously from the marginal utility of full income, which lead to the both saving time, and small size family culture, making of cultural values a relevant part of consumer behavior.

- The business strategic decision before going into international markets must identify the most profitable income segment as a proxy of its cultural bias.

This paper has three sections, (a), The consumer theory: Theoretical background and implications, (b) Consumer and imported goods: A synthesis (c) Consumer behavior and cultural values: Selected empirical evidence which fit the model, and concluding remarks.

\section{a) The Consumer Theory: Theoretical Background}

The classical microeconomic approach started with a theoretical proposal about marginal utility, subjective value theory, human behavior and individual consumption made between $18^{\text {th }}$ and the $19^{\text {th }}$ century Gossen (1810-1858). The Marginal revolution with prominent theorists such as Jevons, (1871), Menger, (1871) and Walras (1874), settle down the foundation of the neoclassical schools about marginal utility. Marshall (1890) developed a better framework with the analytics of the demand and supply curve. Hicks (1939) set the setting to analyze changes in price and income. However, a more systematic approach about consumer theory, started out with the identification of some pattern followed by consumer behavior. The first formal consumer choice theory (1960), was based on the assumptions of rational behavior, but taking into account that consumer choices, do not always fit that pattern because of cultural variables. Besides, although constrained to the organization performance, the bounded rationality concept was already in place. Simon (1957).

However, Becker with his Economic approach to consumer behavior (1976), considered rational consumers not only focused on final goods, but also in the process of spending real income in activities with different combinations of time and goods as necessary inputs to produce them. So, consumers behave like producers mixing their cultural beliefs and dilemmas.

Johnson, (1966), and Chiswick (1967), made further advances, widen up the alternative set for consumers decisions, adding up the time spend at work. Therefore, given that time had a cost (indirect 
one), both at work and at home, consumer behavior even within their rational boundaries (price and income), is not isolated from external influences. Thus, as time become an input, optimal choices are more complex than the conventional two goods bundles. The implication is that the allocation of time, as well as the marginal utility of income, became relevant to understand the complexity of consumer decision making process. Moreover, cultural issues like home activities organization, fertility decisions, education and training, job quality search, and leisure demand at work become essential to consumer decisions not only in terms of resources allocation but also concerning the maximization of full income and its marginal utility. (Becker, 1976).

In the seventies, began a different school of thought the so called Prospect theory, which proposed that decisions are not always optimal, but they instead depend on context. Tversky and Kahneman (1974). All of these developments, led to the following categories of research about consumers. Mowen (1998), Spencer et. al (2004).

- Identify consumer behavior categories. (a); Decision making about choice as a rational behavior (b); Emotions, needs, desires, and innovation pattern, (c), External influence in consumer choice, to override their rationality and emotions. The most prominent in this field, has been the Behavior economics theory.

- The state of the art about consumer theory, which identifies strengths and weakness concerning the research done about it up to the eighties. Sheth (1982)

- The human nature of consumption choices: (a), Rational (b), Irrational (c), Cognitive and (d) emotional. Schiffman and Kanuk (2001).

- The allocation of time theory and its approach to consumer behavior, is in a different brunch, the so called the New approach to Consumer (Producer) Theory. Becker (1962.1976).

Becker (1962), Johnson (1966), Chiswick (1967), Engel, Kollat, and Blackwell (1968), Oort (1969), De Serpa (1971), De Donnea (1972), and Evans(1972), expanded the nature of consumer choices, making clear that it is not just about goods, but also about time and its value, which make the productivity of time in consumption, as relevant as the productivity of time at work, to get the optimal goods combination. Astroza (2012). In these model, consumer evaluates alternative options before making any decisions, setting that choice within a specific time and place framework somehow shaping a set of cultural profiles such as, the weekend to watch movies, late afternoon or early morning to go on jogging, part time schooling, women part time jobs, and so on, leading all to the saving time culture.
The economic approach to consumer behavior (Becker,1976), implied to set a different culture framework (time is money, small size family, e- learning, shopping mall), which made of economics the source of new cultural values for the sake of maximization purposes such that they fit within the rational behavior making them essential part of it. It follows that in this approach, culture values and consumer behavior are within the same optimization framework throughout diversification and adjustment to changing relative prices and income. But as cultural values setting are given in the short run, and quite stable in the long run, consumers worry mainly about their expected increase in income and expected average prices decrease.

As prices are within the microeconomics field, income is highly correlated with the GDP growth and the macroeconomics field. Thus, as consumers end ups to be depending upon both prices and disposal income they both primarily shape their rationality. Thus, with an economic depression, both prices and incomes fall. In the former case it falls because of lack of demand, while in the later, it falls because lack of employment. So, even though it would be irrational not to buy cheaper goods, it is perfectly rational as long as the individual does not have a job which to get income from. It follows that in the short run, price and income rationality may go in different directions. On the other side, while the economy is in the expansion cycle, both prices and incomes rise, in the former case, because of higher demand and wage cost, while in the later one because of higher employment. So, while it is irrational to buy more expensive good, it is perfectly rational to do so, as long as income is higher. So, both income and prices fluctuates over time, but in the long run both settled down on its expected path of price declining and income rising. The implications of this pattern, is that consumers adjust their behavior, to short run circumstances such as recessions or expansion, but in the long run they adapt themselves to income trend. So, if the economy is in a recession high income consumer adjust their consumption, to the expected impact of it in their long run permanent income. Perez (2021)

Other models, such as those of Howard and Sheth (1969); Buying behavior of consumer, Holbrook and Hirshman (1982): the role of products attributes, Sheth, Newman and Gross (1991): characteristics and values, Nicossia (1996): Consumer as a solving standardized problem individual, taking into consideration external influences, made further advances into a new consumer setting. Spencer et. al (2004).

The conventional model, seems very effective to captures the reality of consumer day by day. Utility maximization comes out as the consequence of price changes, given the disposable income which is the constraint maximization is subject to. To the extent that it is fully spend, the expected outcome is the diversified 
basket goods which make of diversification a cultural bias concerning risks behavior.

But there is also a price consideration. As utility increase at a decreasing rate, there is no way to pay the same price for goods whose value is lower, unless prices also decreases, such that the higher real income; allow to buy more of other alternative goods, with higher

marginal utility. It all leads to get into the basket, the proper amount of each good, up to the point of getting the optimal combination for utility maximization.

The standard conditions for a consumer with two alternative goods to chose from (x1, x2), as well as its marginal utility conditions are as follow: Mc Closkey (1982)

$$
\begin{aligned}
& M g U x_{1}\left(x_{1}, x_{2}\right)=P x_{1} * M g U I \\
& M g U x_{2}\left(x_{1}, x_{2}\right)=P x_{2} * M g U I
\end{aligned}
$$

Equation (1) and (2) say that Marginal Utility of good $x_{1},\left(M g U x_{1}\right)$, and Marginal utility of Good $x_{2}$ $\left(M g U x_{2}\right)$, depends on its quantities, and it must be equal to the Marginal utility of Income(MgUI) multiplied by each good price.

However, consumer must stay on its budget line, so it is no feasible to be over or under it. Thus:

$$
I=P x_{1} X_{1}+P x_{2} X_{2}
$$

The marginal utility theory of consumer's choice is set up by these equations; (1) (2) and (3).The marginal utility of Income arise from expenditure on both initial goods. The three equations become a condition for its maximization;

$$
M g U x_{1} / P x_{1}=M g U x_{2} / P x_{2}=M g U I
$$

Equation (4), means that with available income and relative prices, each consumer maximize their utility, diversifying their choices staying away from specialization, but a combination of all available ones.

Making the rearrangement and leaving aside the $\mathrm{MgUl}$, equation (4), becomes:

$$
\Delta U /\left(P x_{1} \Delta X_{1}\right)=\Delta U /\left(P x_{2} \Delta X_{2}\right)
$$

Equation (5) says that, given the prices of goods, the consumer must get equivalent utility increases with each additional amount of goods, keeping total utility constant. When the consumer has reached equilibrium, the lower utility from fewer goods, must be balanced with higher utility of more goods, as he /she moves along the budget lines. .

Rearranging the equation (5):

Which, implies

$$
P x_{2} \Delta x_{2}=P x_{1} \Delta x_{1}
$$

$$
-\Delta x_{2} / \Delta x_{1}=-P x_{1} / P x_{2}
$$

Equation (7) indicates that consumers set their marginal valuation of any of the two additional good equal to the slope of the budget line, (the relative prices), in order to get the combination of goods which maximize their utility.

Either good may be an imported one with lower price $(-\Delta P)$, inducing an increase in its demand $(+\Delta \mathrm{X})$, assuming stable exchange rate $(E=1)$, free market competition. Besides there is not government intervention, such as, tariffs, subsidies, specific taxes, which lead to consumer to lose their gains arising from trade. Thus, choosing a foreign good is a perfectly attainable bundle of goods, among those available at consumer disposal. Rojas-Mendez, Chapa (2020). However, the conventional theories explains mainly the demand situation for two domestic goods, leaving aside considerations about cultural values.

The next step is to get the demand curve, which may be derived by the following two alternative procedures:

a. To maximize utility subject to a budget constraint it gets the Marshallian demand curve:

$$
Q=f(P, I)(\mathrm{P}) \text { : prices, }(\mathrm{I}) \text { : Income }
$$

b. To minimize expenditures subject to an utility function, it gets the Hicksi an demand curve:

$$
\begin{gathered}
Q=f(P, U)(\mathrm{P}): \text { prices, }(\mathrm{U}): \text { Utility } \\
\text { Either way, } \quad \Delta Q / \Delta P<0
\end{gathered}
$$

As prices decreases the purchased amount of any good increases. This is the Law of demand. But, the underlying relationship between price and quantity requires some additional remarks:

a. From equation (4), there is a link between price and value (proxy for utility). Thus, beyond a certain amount of any good whose value is decreasing, consumer does not want such useless good even whether it is free. It follows that the law of demand, explain the price reaction of consumers toward good whose relative value is decreasing, setting a lower limit to the price they are wiling to pay. Therefore, prices and values, moves in the same direction.

b. Goods of high value are within the area of the consumer surplus, which means that as the value of any good increase, so it will be its price. Alternatively, as consumer demand goods with higher value, they are willing to pay higher price. This is the Law of Value, which is derived from the marginal utility of income set in equation (4).

c. The expenditure decision is a reliable proxy for consumer preferences. When it comes about the law of demand, prices matter, but when it come about the law of value, income matter. 
d. Imported goods are left out of the optimal bundle. However, the revealed preference theory, make clear that imported goods become an alternative within the consumers preferences.

e. The revealed preference approach, make the law of demand a fact of consumer choice either for domestic or imported goods. So, measurable utility is not a condition to get the quantity demanded of any good, either domestic or imported.-

The Revealed preference Theory (Samuelson 1938), make of consumer choices a logical sequence after changes in prices and real income. There are two version of it: the weak (WARP), and the stronger assumption of revealed preferences (SARP).

The WARP (weak axiom of revealed preferences), says that whether consumer buy regularly a good "B", despite other alternative available (good " $C$ "), within their budget attainable area, it is because " $\mathrm{B}$ " is preferred to "C".-

The SARP, says that given the real income, when there is changes in relative prices, which allow a different combination of goods, it works the transitivity theorem, which means that if "good A" arising from the new relative price is preferred to "good B", and "good $B$ " is preferred to "Good C", then "good A" is preferred to " C". Samuelson (1938), Mc Closkey (1982), and Romero (2014)

Given that consumers in Stage (0) has at their disposal, two goods $\left(x_{1}\right.$ and $x_{2}$ ), but in stage (1) also has imported goods $\left(x_{3}\right)$ to add into their goods bundles, it follow that:

The consumer in stage (0), has two domestic produced goods " $x_{1}$ " and " $x_{2}$ ", with " $P x_{1}$ " and " $P x_{2}$ " respectively spending all of their income (I) in bundle $\left(E^{1}, 2\right)$, to get the utility maximizing condition.

So, given that while " $x_{1}$ " lead consumer to stay on the budget line, spending all of their available income, while " $x_{2}$ " is also available but it is below their budget boundaries, consumer will chose " $X_{1}$ " over " $X_{2}$ "

$$
E_{1} \geq P x_{1} X_{2}
$$

From equation (9), it follows that consumer has revealed their preference for bundle " $x_{1}$ ", in which all of their income is spend, instead of spending in " $x_{2}$ ", whose expenditure is below the feasible expenditure area.

$$
E x_{1}=P x_{1} X_{1} \rightarrow E x_{2}<P x_{2} X_{2}
$$

Consumers reveal their preference for " $x_{1}$ "instead " $x_{2}$ ". This is the Weak axiom of revealed preference (WARP), as long as the consumer decisions is concern, given that $X_{1}$ was also available but the expenditure the consumer is willing to make on it, is less than the income available.

But, how all of this situation would change whether the economy engages in a free trade policy?
This leads the situation to the following stage (1). With free trade imported good $\left(x^{3}\right)$, which has lower prices than its domestic substitute let say $X_{1}$. The new compensated budget line, create a different set of choice for goods $\left(x^{3}, x^{2}\right)$. So it does make possible for consumer, to increase their goods bundle, adding up imported goods. Given a compensated change in prices, $E x_{3}=P x_{3} X_{2}$ which means the " $X_{2}$ " is still available, but at a higher price $\left(P x_{2}>P x_{3}\right)$.

Therefore, the budget situation becomes:

$$
E x_{3}=P x_{3} X_{2}, \quad E x_{2}<P x_{2} X_{3}
$$

Therefore, given both $E x_{2}=P x_{2} X_{2}$, and price compensated expenditures (11), $E x_{2}<E x_{3}$. It means that while $E x_{3}$ expenditures, are in the new compensated budget line $E x^{2}$ is within the former expenditure zone. Therefore, its utility curve is below than that one of $X_{3}$.

$$
P x_{2} X_{3}<P x_{3} X_{2}
$$

(12) leads to:

Rearranging terms and adding up expression

$$
P x_{2} X_{3}-P x_{3} X_{2}<0
$$

It leads to: $\triangle P \Delta E<0$

$$
\text { where } \Delta P=\left(P x_{2}-P x_{3}\right) \text { and }\left(\Delta E=X_{3}-X_{2}\right)
$$

Condition (14), says that given everything else constant, imported goods available at lower prices than domestic ones, will change the goods bundle, such that consumers increase their demand for those foreign goods. This is the Strong assumption of revealed preferences, which applying the transitivity theorem, it means that if imported good ( $x_{3}$ ") is preferred to $\left(x_{1}\right.$ ") and, (" $x_{1}$ ") preferred to ( ${ }_{2}{ }_{2}$ "), then ( $x_{3}$ ") is preferred to (" $\left.x_{2} "\right)$. Where $\left(x_{3}\right)$, is the imported good which substitute $\left(x^{1}\right)$, but $\left(x_{2}\right)$, is the remaining domestic one.

Therefore, based upon expenditures on $X^{3}$ which fit consumer preferences, its demand curve arise from it. This outcome, allow to connect rational behavior of utility maximization, with real expenditures decisions, Romero (2014). In other words, it is not necessary the utility function, neither to get the demand curve for domestic nor imported goods. As equation (13) suggest, it is sufficient to have expenditures on such a good ( $X^{3}$ "), or for this matter any imported goods, to get its demand given their income level.

\section{ili. The Marginal Utility of Income: Personal Needs Step up}

Equation (5), which leaves aside the marginal utility of income, miss the general microeconomic setting for understanding the consumer choices within a wider format concerning domestic and imported good, 
and its link to the expected income trend. So, while prices stabilize in the long run, income levels trend is to increase, which make consumer choices over time, dependent upon income changes. This is what has made of the macroeconomic theories of consumption (Keynes (1936), Duesenberry, (1937), Modigliani, et al (1954) and Friedman (1957), a starting point for policy making about aggregate spending. Perez (2021)

From consumer's point of view, prices solve the choice about alternative goods. Instead, income level widen up consumer choices to a more comprehensive and complex understanding of their behavior. Income means to take into account the Value Law. Besides, as income rises consumer needs step up making possible wider connection with other disciplines, and expanding at the same time the meaning of marginal utility of income, especially in the high income consumer segment to shape their behavior and rationality boundaries. It follows that:

- The "Law of Value", refers to qualitative and subjective variables tied up to higher prices (quality, status, image, prestige, durability, multi functionality and so on), which higher income can afford, but it also refers to the efficiency and quality of transactions, which lead to the perceived quality of the deal. Thaler (2015).

- The "Law of Value" says that as income levels increase, and so it does the expected value attached to any good the higher the price which consumer will be willing to pay.

- In other words, it is perfectly rational for a consumer; to pay higher prices for goods and its perceived high value, should incomes levels allow them to do so. Levinson and Pen (2007).

The implications the Law of Value for business strategic decisions in foreign markets are that it should focus on increasing the value endowment of each good the firm is planning to put into those markets. Therefore, their best strategy becomes to concentrate on high income consumer where its benefits will come from.

Moreover, higher income level allows different social interaction which it creates new needs, so the culture values become more influential on consumer behavior. Levinston, et. al (2007) Maslow proposed that as incomes rises, needs step up from the basic to the more advanced stage. High income people's need are the status, prestige, ego and self realization, different to those in low income levels within the basic stage level. As equation (4) suggest, this different position in the income scale, make them to have different marginal utility of income. While high income consumers, get the most of their marginal utility of income, choosing a wider variety of good from abroad at their own style, low income consumers marginal utility of income deal with the ability to get done the basic daily needs.
Therefore, as consumer thinks of value more in relative than absolute terms, (Thaler, 2015), the relative income framework allows the demand fragmentation, which moves consumers away from standardization for the sake of getting the highest marginal utility of their relative income. This outcome explain on the one side the demand for luxury cars, private planes, first class tickets for long distance flight, fashion design clothes, gourmet restaurants, antiques, jewelries, smart watch, sophisticated cell phones, on demand product, branding, and the likes, with high quality on its transaction process, which lead business to identify these high profit cosmopolitan consumer, as a target for its strategy in foreign markets. Rojas-Mendez, Chapa, (2020).

Thus, as income increases, it improves its relative stance, such as to widen up consumer options for better quality goods with high value endowment, shaping consumer behavior, as well as the boundaries of rationality. Ariely (2008). There is a strong relationship, between the Law of value, its more complex needs as well as its ordinal sequence. As consumers moves into higher income segment, their value assessment become more decisive, which it allows consumer to reach out other subjective variables such as solidarity, consciousness, brand loyalty, prestige and the like which make the cultural setting a component of social behavior. Goldschmidt (2012)

Moreover, the relative income hypothesis, (Dussenberry, 1937), does make consumer to compare themselves with all those in the same income branch before deciding what to buy, whether they are at home or abroad. Therefore, imported goods whose relative value endowment (Brand, prestige, status and the likes), is higher than domestic goods, whose transaction cost is lower and its efficiency is higher, it increases the marginal utility of relative income.

Relative Income becomes the driver, for consumer to look up for more sophisticated needs, connecting cultural values with a variety of different goods (foreign, green, organic, diet goods). So, when business face consumer choices in international markets, they all need to focus on is in Consumer Income and its expected trend over time, as the proxy for cultural values and it meaning for consumer choices. However, the income segmentation in countries like the EU; USA, East Asian Countries, or Japan, are quite different to the LDC countries or emerging economics which have both lower average income levels, a wider income gap, which suggest a cultural gap.

So, back to equation (4), the maximization of marginal utility from basic goods, is directly related to the marginal utility of income at the stage 0 as it fulfill basic needs. In so doing, income is the absolute constraint. However, as income rise up over time to the following stages $(S 1 \ldots, S n-1)$, the scope of its marginal utility grows wider reaching out to more 
complex attributes of goods, away from those in stage 0 .

Therefore, as free trade makes available imported goods, in these advanced stages they becomes an alternative to domestic expensive good, because its substitution elasticity is high. The expected value endowment of foreign goods, make of the marginal utility of income the driver for consumer decisions. So from equation (4), it follows that:

- As long as the foreign goods have better value endowment, higher income consumer will prefer to buy them, because they can both afford to do so, and those goods provide them a higher marginal utility of their income (prestige, status, style, sophistication, elegance).

- Foreign Goods Subjective Values becomes like a superior good such that the higher the income level, the higher its share on consumer choices. So, as incomes increase over time it shapes different consumer behavior pattern as well as their rational boundary to do so.

\section{Consumers and Imported Goods: A SYNTHESIS}

International trade means a wider variety of goods available at lower prices, and on average, with higher quality standard. Besides, trade does not only mean lower price for imported goods, buy also an increase in income levels over time, which can be allocated to a mix of domestic and foreign goods, leading to a substitution and income effect respectively. Thus, over time both effects lead to buy more imported goods. The strength of both effects for imported goods, depend upon a wider variety of variables starting with prices differences, relatives incomes, as well as those qualitative value attributes (quality, technology, service, brand), as differential factors, which high income consumers are willing to pay for. However, as far as the Equation (4) is concern, the income effect becomes stronger as income grows over time.

From equation (4) it comes out an income and a cultural gap. Those consumers on the top of income level, have values and cultural setting, different from those at the bottom, because the focus of their expenditure on this income stage (Stage 0), is on basic goods (foods), and their incomes effects from cheaper imported goods is lower. So, their pattern behavior is different. Ariely (2008).

Furthermore, in case that technological change is faster abroad than at home, it means imported goods may be designed to save time for the sake of its productivity in consumption reinforcing its demand, because it allows more time for leisure, family, friends, recreation, entertainment, and the like; all of which lead to increase in consumer welfare levels, due to a more efficient allocation of time. (Becker 1976).
Equation (13) suggests that imported goods fit within the optimization framework. Foreign goods have attached qualitative attributes, which expand the meaning and scope of relative income and goods value maximization. Relative Income becomes a decisive variable in consumption decision, concerning the expected demand for value, as well as the cultural meaning attached to it. Levisnton (2007), Thaler (2015).

Thus, in Latin America economies, with low average incomes levels, the scope of culture values and its impact on consumer decisions is more limited. Low income consumer, do not demand goods based on style, image or prestige. To do so, they need to have higher income. These differences have to be considered when it comes to make comparatives studies, to make of the impact of cultural variables a more reliable reference. Rojas-Mendez-Chapa (2020)

\section{Cultural Values and Consumer Choice: Selected Empirical Evidence}

Cultural values are considered to be a different branch of consumer behavior, mainly within the area of phycology. Schiff man (2005), Kotler (2008). However, there is important evidence which support cultural values influencing the assessment that consumers make, as well as their behavior and rationality about their decisions. Heinrich (2000), Levinson (2007), Goldschmidt (2012), Samson (2014) and Marim (2016). Rojas-Mendez, Chapa (2020).

Thus, the case about the relevance of healthy food to get better quality of life, it makes those organics goods worth to pay higher prices. Its marginal utility is on the one side, attached to the marginal improvement in the quality of the diet the consumer look for. On the other, it increases the marginal utility of higher income as it gets a higher value due to better quality of life over time.

Moreover, it is important to make a distinction between cultural values as a matter of tastes and preferences arising from incomes levels, (social interactions), and cultural values as a matter of a structural setting arising from inherited cultural values, beliefs and ideas which are the core of a society. These setting are the boundaries which individuals live into. It includes the status of women, average education level, literacy, inequality and poverty, access to banks services, gender gap, law and institutions, state of consciousness about key issues, religions values, Racial discrimination, individual characteristics (average height, weight, size), the relevance of merits and incentives, languages profile, and the like. Marim (2016)

Thus, producing washing machines for women in Europe must have a different height, compared to that ones made for women in Japan. Alternatively, the clothe size $\mathrm{XL}$ does not fit too much in Latin American countries as it does in USA and Europe. 
Consciousness about the environment, mean consumers to expect pro environment seal on the good they buy.

Besides, the public policy about healthy food, may lead to lower consumption of fast food, as it is the campaign to get rid of tobacco, to keep seat belts on while driving, to drink sugar free soft drinks, or to use free hand devices for cell phones while driving a car, all of them defining a way of life, any individual want to be part of. It is well known the relevance of both public and cable TV commercial, on consumer choices. Therefore, there are two cultural forces acting on consumer behavior

a. The structural inherited cultural setting, which defines the institutional boundary consumers belong to.

b. The individual cultural preferences, arising from higher income and its marginal utility, as a determinant of their expenditures. (prestige, image, status and the like).

So, as far as consumer choices are jointly determined by (a) and (b), each one has its share in their final decision to buy or not any good either domestic or imported one. In doing so and as far as it is less costly to adapt than to deviate from them, the scope of rational behavior reach out to subjective values which become endogenous variables to count on consumer decisions.

Therefore, consumer behavior is a complex field about human choices with a multidisciplinary set of determinants, which requires a deeper and broader attention to other disciplines beyond economics, such as anthropology, sociology, social psychology and ecology. Heinrichs (2000) Levinson (2007), Marim (2016). At the same time the institutions as a public good provider (law, policies, rules), also fit into the consumer behavior format. North, (2001).

There are different models to explain the influence of the cultural setting, such as those in the field of transcultural models, and the role of languages. Osgood (1967). A significance research has been done since early seventies about it starting from the USA cultural profiles, leading to criticism about ethnocentrism bias (every one need to learn English), misleading the significance of other key variables. Spence ret. al (2004). However, the justification for this kind of trans cultural studies, is within the area of international marketing, as firms go into global market, and its first requirement becomes to know the consumer characteristics before setting its business target.

Moreover, to shape their behavior consumer face multiple types of influence, such as those linked to their income and prices constraint as internal influence (Becker (1976)), and those linked to the particular cultural framework as external influence, which their choices are madefrom (Marim (2016)). Individual behavior is shape by this two channels either directly (marketing mix) or indirectly (cultural setting), leading to higher preferences for specific kind of goods (expensive imported goods, organic goods, sugar free and the like), all of them beyond the basic price setting, and more on the side of value and income available.

It follows that with income gap between the high income and low income segment, it is not possible for international business to assume market homogeneity, but to set on each one its own target. Rojas-Mendez, et. al (2020).

There are two alternative of approaching the dimensions which are determinant of social behavior:

- Hofstede (1991), who proposed five dimension to analyze the determinants of social behavior: distance to power, male dominance, individualismcollectivism, Uncertainty aversion, and long run prospect. Spencer. et al (2004). Yoo, Donthu, and Lemartowicz. (2011).

- Triandis (1994) and later on Lee (2000) proposed, three variables as determinants of social behavior: culture, past experience, and behavior reaction to specific perceptions. This last factor may be considered as a proxy of the relationship between perceptions with relative income and prices levels, which lead to cultural values to influence consumer behavior.

Spencer, et.al (2004), considered the Hofstede model (1991) to study Chinese and Chilean consumers, which lead to the conclusion that the cultural setting does influence Chinese consumer behavior and their choices. In particular as the equation (4) suggest, $50 \%$ of them are willing to pay for expensive foreign goods, and those in the segment of higher status, and young urban professionals (yuppies), have remarkable preferences for foreign goods (Color TV), with 62,2\% and $50 \%$ respectively. Besides as equation (13) predicts, $63,5 \%$ of the middle class have preferences for foreign goods, such as air conditioner with $14,9 \%$ and $30,8 \%$ respectively, as well as the life insurance programs from foreign companies $(41,9 \%$ and $40 \%$ respectively). All of which is a signal of admiration for foreign goods, and support of xenocentrism. But the Chinese and Chilean consumer decisions about food, transportation, and entertainment are all influenced by their relative income, no matter their differences on their cultural settings. Thus, following equation (4) it makes clear that equivalent income levels in Chinese or Chilean consumer, lead to very alike buying preferences on basic goods. But as income rise both Chinese and Chilean consumers, are willing to change although in a difference pattern, their preference toward foreign good to maximize its marginal utility. 
There is also the symbolic cultural model, which identifies the influence of regional cultural variables, and its ethnocentrism component. Páramo (1999). In this case consumer behavior is determined by their perception about qualitative attributes of any good, whether it is either positive or negative. This is the case of friendly environment goods, which consumer may feel engaged with. These models, propose a descriptive relationship between cultural variables, and its relevance for consumer behavior. This is so, due to the fact that consumers do not lose their condition of being citizens, family members, workers, which provide a multi dimensions set of variables, to influence the social interaction within which they make their choices. Rationality does not mean to stay over that constraint, but given that none of these cultural variables change in the short run, it proposes a path to make possible that in such a case, consumer regular decisions over time, allow a systematic increase in their welfare levels. North (2001, pp 34), Marim (2016)

A recent paper (Rojas-Mendez et.al (2020)) focused on xenocentrism as predictor of consumer intention to purchase goods following a three stage analysis. Starting with Mexican consumers, then the next step to get a cross cultural measure of convergence with their Mexican counterparts was to include consumers from three Latin American countries (Equator, Colombia and Peru). Finally it considered the Chinese consumers. The working hypothesis was that in the Mexican consumer case, xenocentrim represent preferences for foreign goods and dislike for domestic goods, asa signal of a social phenomenon associated with the status and the self esteem that foreign goods consumption provide. To check xenocentrism bias, a sample of 213 MBA Chinese students (66\% females, $34 \%$ had not visited a foreign country, and $64 \%$ were 34 years old), was asked to make an evaluation between 14 domestic brands and 16 foreign ones. The outcome validated the admiration toward foreign goods, and the rejection of domestics ones for all product categories, which it was consistent with the Triand is three dimension Model (1994), and that one of Spencer, et.al (2004) which followed the Hofstede model.

As far that admiration may be linked to the expected price - value relationship of selected foreign goods, because its higher transaction process efficiency, (payment alternatives, guarantee policies, post service, customer management policy), as well as the high value attached to traditional foreign brand, it is consistent with equation (13). On the opposite side with lower expectation about price -value relationship, which is the case of massive standardized good within the low income status, the lower the xenocentrism and the more likely for Chinese consumer to buy domestic goods. Rojas-Mendez, Chapa (2020).

The Rojas-Mendez et al (2020) paper concludes that consumer with a positive feeling about domestic goods do not instantaneously reject the alternative of buying foreign goods. As equation (4) suggest this may be explained on the one side by their expectations about the long run increase in their income level and its marginal utility in foreign goods, as well as the diversification profile of utility maximization. This does not mean to overlook the relevance of cultural values. They are within the set of values and beliefs which make self evident in consumer preference for diversification. In other words, cultural values do not stay outside the consumer framework but they are inside of its maximization purposes although it is not self evident given the individual nature of the marginal utility of income.

As expression (11) suggest, foreign goods increase the marginal utility of income, more so for those consumer with high Income. Thus, in the advanced stage of Maslow scale (1943), when ego and self esteem needs become the driver for consumers who already have reached that status, it make them an essential part of the business strategy for profit. Therefore, as far as xenocentrism means the over valuation of foreign goods attributes, it becomes a proxy of its endogenous component (status, image and the like), which increase the marginal utility of income leading to higher demand for them. Besides, following equation (13), as prices of foreign goods are lower than domestic ones, the revealed preference induces higher demand for imported goods.

Moreover, the dislike component for domestic goods and its replacement for foreign goods, arise from the higher value endowment expected from the latter, as a side effect of equation (4). This is the case of those imported good which provides a signal of style and sophistication to cosmopolitan customers and their self esteem for whom to wear a Rolex watch means a symbolic value attached to higher stage of consumption status, which induce to buy expensive cars, clothes, jewelry and the like. In fact, there is a positive relationship between cosmopolitanism and xenocentrism. Rojas -Mendez - Chapa (2020).

The lower income consumers may also decide the same path concerning foreign goods as they decide based of their relative income, which mean to compare themselves with their foreign counter parts, so they buy foreign goods they can afford, like microwaves, TV set, cell phones, medium size cars, tourism and so on. Spencer et.al (2004), Rojas-Mendez, Chapa, (2020). But, this does not mean that those consumer react in the same way higher income consumers do, as much as the former are driven by prices, while the later are driven by value. Thus for low income consumer demand for foreign goods of higher value, are left out of their bundle precisely because those goods are more expensive, quite the opposite to the behavior pattern for higher income consumer This make for each income segment a different behavior profile. Ariely (2008) 


\section{Vi. Concluding Comments}

Consumers have a mixed cultural dimension profile. They are citizens, family members, and workers. They also have values, beliefs, principles, dreams and expectations. So, there are different disciplines whose purpose is to explain these values to get a better understanding about their behavior. Neoclassical theory use a utility maximization models focusing in prices (Given Income and preferences), as a source of information for consumers decisions. However, Incomes deals with social interaction values and as it increase over time, needs step up and the marginal utility of Income shapes the boundaries of rationality and the consumer behavior.

Cultural values represent an exogenous common ground for consumer decisions mostly stable in the short run, which in the long run provide cohesiveness to society as the essential framework for other values to develop, such as stability, the rule of law, honesty, transparency, solidarity, ethics which consumer are not fully aware of in the short run, but it would not be possible to think about increasing the welfare level without consider them in the long run. Thus, rationality assumption does not means necessarily to reduce human complexity to cost -benefits choices, but to provide a path to make those choices the most valuable one over time. This does not mean to overlook the relevance of cultural values. They are part of consumers framework and its maximization purposes, mainly through their diversify behavior, as well as the framework they considers to decide the allocation of their time between different alternative activities, which lead to new cultural values such as saving time which make of them part of the setting for resources optimization.

Marginal utility of income analysis, provide a consistent explanation how come those social variables get into consumer framework, as well as its relevance for their decisions. Besides, it provides an explanation to the Law of Value, which shape consumer behavior as it increases over time which leads to preference for high quality foreign goods. So, the marginal utility of income it shapes the boundaries of rationality and with it the consumer behavior. Moreover, the revealed preference theorem in particular, is a fact-based explanation for consumer to demand foreign good. Therefore, to wear a Rolex watch means a symbolic value attached to income and its marginal utility, moving up the stage of consumption status, to other foreign goods as it is to buy expensive cars, clothes, jewelry and the like.

When it comes to imported cheaper prices good, lower income consumers, may also decide to buy them as they compare themselves with their pairs. Thus, they buy foreign goods like microwaves, TV set, cell phones, computers, and so on. But, this does not mean that consumers with a higher share of their expenditures on basic goods react in the same way as their counterparts with higher income. Thus, foreign goods of higher value are left out of their bundle, precisely because they are more expensive and their income elasticity to foreign goods is lower.

The selected empirical evidence, support the positive relationship between cosmopolitanism and xenocentrism. This is consistent with consumer revealed preference for domestic goods, and low levels of xenocentrism, as far as it all deal with differences in income levels. Therefore, Microeconomics provides a reliable theoretical explanation about consumer decision, cultural values and their behavior, either in case of choosing domestic, foreign goods or a mix of them within their bundle. As income goes up, it boots different needs expanding the decision setting both to cultural values and with it to the mixed dimensions of consumer behavior widening the boundaries of rationality.-

\section{References Références Referencias}

1. Ariely, D (2008). Predictably Irrational. New York Harper Collins

2. Ariely, D, Loewenstein, G \& Prelec, D (2003). Coherent arbitrariness: Stable demand curves without stable preferences. Quaterly Journal of Economics, 118, 73-105

3. Becker, G. (1962). Irrational Behavior and Economic Theory. The Journal of Political Economy, 70 (1), 113.

4. ---------, (1976). Aneconomic approach to Human behavior. University of Chicago Press

5. Bettman, J. (1979). An information processing theory of consumer choice. Reading MA, Addison Wesley Ed. (Reference by Spencer, Mora and Yeh, (2004))

6. Bossaerts, P \& Murawski, C (2015). From behavioral economics to neuroeconomics to decisions neuroscience: the ascent of biology in research oh human decision making. Current opinions in Behavioral Sciences. 5, 37-42.

7. Brooks, D (2012). The social animal. B. S. A Editions. Barcelona. Spain

8. Engel, J. Kollat, D. \& Blackwell, R. (1968). Consumer Behavior. Holt, Rinehart and Winston Ed. (Reference by Spencer, Mora and Yeh, (2004))

9. Gigerrenger, G \& Goldstein, D. (1996). Reasoning the fast and frugal way: Models of bounded Rationality. The Psycological Review, 103, 650-669.

10. Goldschmidt, N (2012). A cultural approach to economics. Intereconomics. Vol 41. Issue 4,176-182

11. http://dx.doi.org/10.1007/s10272-006-0188-1

12. Hofstede, G (1991). Cultures and Organizations: Software of Mind. Mc- Graw Hill International. London. 
13. Holbrook, M. \& Hirshman, E (1982). The experiential aspects of consumption: consumer fantasies, feelings and fun. Journal of consumer research. 9,132-140. (Reference by Spencer, Mora and Yeh, (2004))

14. Howard, J. (1963). Marketing Management: Analysis and Planning. Illinois, Homewood Ed., Richard D. Irwin. (Reference by Spencer, Mora \& Yeh, (2004))

15. Howard, J. \& Sheth, J. (1969). The theory of buyer behavior. New York, John Wiley Ed. (Reference by Spencer, Mora \& Yeh, (2004))

16. Johnson, E, \& Ratcliff, R (2014). Computational and process model of decision making in psychology and behavioral economics. Chapter III. 35-35. Neuroeconomics. Decision making and the brain. $2^{\text {nd }}$ Edition. Glimsher, P and Fehr, E. Editors. Elsevier. USA

17. Kahneman, D (2003). Maps of bounded rationality: Psychology for behavioral economics. The American Economic Review,93, 1449-1475

18. Kahneman, D (2011). Thinking fast and slow. London. Allen Lane

19. Kotler, P (2008) Dirección de Mercadotecnia. Prentice Hall. 4ta Ed. México

20. Lee, J (2000). Adapting Triand is model of subjective culture and social behavior relations to consumer behavior. Journal of Consumer Psychology. 9 (2), 117-127. (Reference by Spencer, Mora \& Yeh, (2004))

21. Levisnton, J \& Kalping, P (2007) Valuing Cultural differences in Behavioral Economics. Journal of Behavioral Finance, Vol 4, No1,32-47

22. Marim, A (2016). Cultural Beliefs, values and economics: A survey. Munich Personal Re PEc archives, MPRA,No 69747,1-30.https://mpa.ub.unimenchen.de

23. Maslow, A. (1943). A Theory of Human Motivation. Psychological Review, 50, 370-396.

24. Modigliani, F. \& Brumberg, R. (1954), Utility Analysis and the Consumption Function: An Interpretation of Cross-Section Data. The Collected Papers of Franco Modigliani (2005), Editor F. Franco, MIT Press.

25. Mc Closkey, D (1985). The applied theory of prices.2nd Edition. Mc Millan Publishing Company. New York.

26. Mowen, J (1998),. Consumer Behavior. Upper Saddle River. Prentice Hall Ed. (Reference by Spencer, et. al (2004)).-

27. Nicossia, F (1996). Consumer Decision Processes. Englewood Cliffs N J. Prentice Hall.

28. North, D (2001) Institutions, Institutional changes and Economic Performance. Cambridge University Press. FCE. Mexico.

29. Osgood, C (1967). On the strategy of cross national research into a subjective culture. Social science information. 6 (1), 5 - 37. (Reference by Spencer, et. Al (2004))

30. Paramo, D. (1999). Hacia un modelo simbólico cultural del comportamiento del consumidor. Revista Pensamiento \& Gestión. División de Ciencias Administrativas. Universidad del Norte. Barranquilla. №7. (Reference by Spencer, et.al (2004))

31. Perz, D (2021). The micro anatomy of macro consumption adjustment. Webinar series .Central Bank of Chile. www.bcentral.cl

32. Heinrich, J (2000). Does cultural matter in economics Behavior. Ultimatum game bargaining among the Marhiguenga of the Peruvian Amazon. The American Economic Review. Vol 90,Nº4,1-12

33. Hofstede, G (1991). Cultures and Organizations: Software of Mind. London, Mc- Graw Hill International Ed. (Reference by Spencer, et.al (2004))

34. Rojas-Mendez, J \& Chapa, S (2020)."X-Scale: a new scale to measure consumer Xenocentrism", Marketing Intelligence and Planning, 38(3), 354-368.

35. Romero, I (2014). Consumer behavior from three different theories.www.revistanegotium.org.ve $\mathrm{N}^{\circ} 29$, Año 10,130-142.

36. Samson, A (2014) Behavioral economics guide. www.http://behavioraleconomics.com

37. Samuelson, P. (1938). A note on the pure theory of consumer behavior. Económica, 5(17) ,61-71

38. Simon, H (1957). Model of man, social and rational. John Wiley \& Sons. New York

39. Simon, H (1982). Models of bounded rationality.Canbridge. MA. MIT Press

40. Schiffman, L \& Kanuk, L. (2001). Comportamiento del consumidor. 7ma Edición. Pearson Educacion. México.

41. Schiffman, L (2005). Comportamiento del consumidor. Prentice Hall. 8a Ed.

42. Sheth, J. (1982). Consumer behavior: surpluses and shortages. Advances in consumer research. 9 (1), 13 - 17. (Reference by Spencer et.al,(2004))

43. Sheth, J. Newman, B \& Gross, B (1991). Why we buy what we buy? : A theory of consumption Values. Journal of Business Research. 22 (2), 159-170. (Reference by Spencer, et, al (2004))

44. Spencer, E, Mora, R \& Yeh, P (2004). Conductas del consumidor en el ámbito internacional: Elementos para un análisis comparativo. Consumer behavior within international setting: Element for a comparative analysis. 1-126. Faculty of Economics and administrative Sciences. University of Chile. Santiago

45. Thaler, R. (2008) Mental accounting and consumer choice. Marketing Science,27,15-25

46. Thaler, R (2015). Misbehaving: The making of behavioral economics. Allen Lane 
47. Triandis, A \& Kahneman, D (1974). Judgement under uncertainty: Heuristics and biases. Science, $185,1124-1131$.

48. Triandis, A (1977). Interpersonal Behavior. Monterey, Ca. Brooks. Cole

49. Triandis, H (1994). Culture and social behavior. New York, Mc Graw-Hill Ed. (Reference by Spencer, Mora \& Yeh, (2004).

50. Yoo, B, Donthu, N \& Lenartowicz, T (2011). Measuring Hofstede's five dimension of Cultural values at the individual level. Development and validation of the CVSCALE. Journal of international Consumer Marketing, 1-17. 